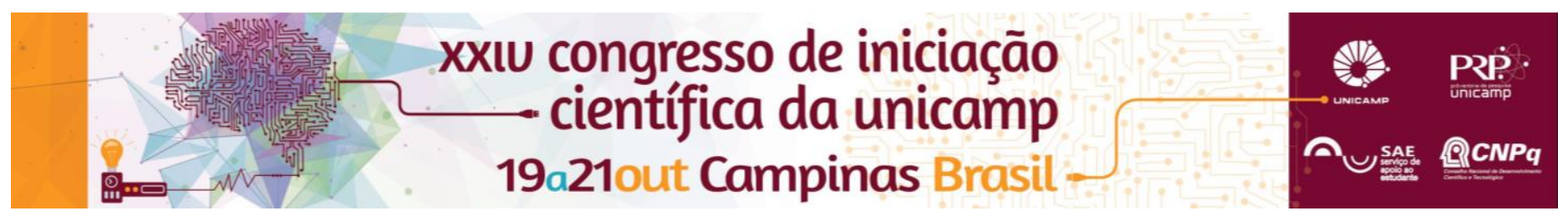

\title{
Gluten free breakfast cereal from red sorghum wholemeal, brown rice and defatted chia flours.
}

\author{
Guilherme F. B. Gibelato*, Lucas K. T. Hori, Marcio Schmiele, Wellington S. Oliveira, Helena T. Godoy, Yoon K. \\ Chang.
}

\section{Abstract}

Breakfast cereals are a good choice to be incorporate in the breakfast meal. Therefore, few kinds of these cereals can not be eaten by people with celiac disease due the permanent gluten intolerance, due the presence of proteins from wheat, barley, rye and/or oat. The aim of this work was to develop a breakfast cereal by the mixes of three gluten free flours (sorghum, rice and chia), in order to give a product source of fiber, gluten free and with health benefits, such as reduced glicemic index, improving protein digestibility and with consid erable levels of essencial fatty acids.

\section{Key words:}

Celiac disease, dietary fiber, glycemic index.

\section{Introduction}

Gluten is composed by a tridimensional viscoelastic protein network which promote physical and rheological characteristics such as plasticity, viscosity and elasticity ${ }^{1,2}$. An option to replace the cereals (wheat, oat, rye and barley) which present gluten proteins, it can be used cereals (rice, corn and sorghum) or pseudocereals (buckwheat, quinoa, chia and millet) ${ }^{3}$.

Thus, the extruded cereals become a good choice for developing gluten free products, with increasing the fiber levels when used in the whole ground grain.

The aim of this work was to elaborate gluten free breakfast cereal, source of fibers, using red sorghum wholemeal $\left(\mathrm{x}_{1}\right)$, brown rice flour $\left(\mathrm{x}_{2}\right)$ and defatted chia flor $\left.\mathrm{x}_{3}\right)$ through a simplex-centroid mixture design,

\section{Results and Discussion}

The chemical composition of the raw materials is presented in Fig. 1(a). The technological properties were evaluated in order to determine the mathematical models and the surface responses, and the goal was a breakfast cereal with at least $10 \%$ defatted chia flour, but with a low compression force and apparent density and a high expansion index and water solubility index. Thus, it became possible to establish an optimal point (Fig. 1(b)), composed by $67 \%$ red sorghum wholemeal, $23 \%$ brown rice flour and $10 \%$ defatted chia flour, resulting in a desirability 0.61 . Table 1 shown the data obtained by the analysis of the optimal point. There was observed that while the expansion index increase, also occurred an increase in cold viscosity and water solubility index and a decrease in compression force, apparent density and peak viscosity.

Figure 1 - Raw material chemical composition (a) and image of optimal point of gluten free breakfast cereal (b).

(a) $\backsim$ Red sorghum wholemeal $\backsim$ Brown rice flour $\quad$ Defatted chia flour

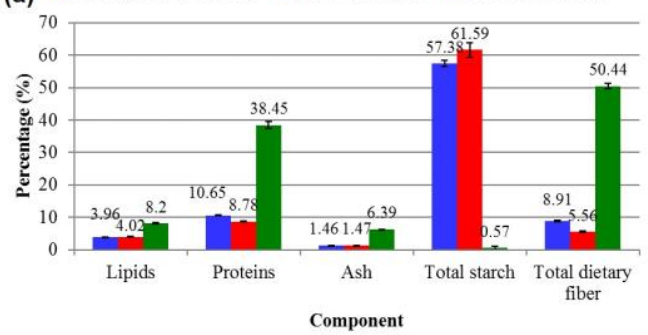

(b)

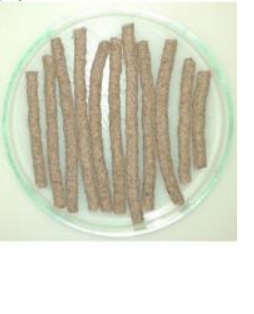

Table 1 - Data obtained for optimal point analysis

\begin{tabular}{|c|c|c|}
\hline \multicolumn{2}{|c|}{ Parameters } & Results \\
\hline \multicolumn{2}{|c|}{ Cold viscosity (cP) } & $765 \pm 35$ \\
\hline \multicolumn{2}{|c|}{ Peak viscosity (cP) } & $769 \pm 36$ \\
\hline \multicolumn{2}{|c|}{ Compression force $(\mathrm{N})$} & $13.33 \pm 0.08$ \\
\hline \multicolumn{2}{|c|}{ Water solubility index (\%) } & $7.70 \pm 0.28$ \\
\hline \multirow[t]{2}{*}{$\begin{array}{l}\text { Instrumental } \\
\text { color }\end{array}$} & $\begin{array}{l}L^{*} \\
a^{*}\end{array}$ & $\begin{array}{c}44.10 \pm 2.17 \\
7.87 \pm 0.28\end{array}$ \\
\hline & $b^{*}$ & $10.78 \pm 0.47$ \\
\hline \multicolumn{2}{|c|}{ Apparent density (mg.mm³) } & $0.28 \pm 0.02$ \\
\hline \multicolumn{2}{|l|}{ Expansion index } & $2.33 \pm 0.08$ \\
\hline \multicolumn{2}{|l|}{ Glycemic index } & $58.21 \pm 1.50$ \\
\hline \multicolumn{2}{|l|}{ Glycemic load } & $9.20 \pm 0.24$ \\
\hline & C $16: 0$ & $16.49 \pm 0.21$ \\
\hline \multirow{5}{*}{$\begin{array}{l}\text { Fatty acids (\% of } \\
\text { area) }\end{array}$} & C $16: 1$ & $0.48 \pm 0.03$ \\
\hline & C $18: 0$ & $1.02 \pm 0.07$ \\
\hline & C $18: 1$ & $21.14 \pm 0.59$ \\
\hline & C $18: 2$ & $47.02 \pm 0.59$ \\
\hline & C $18: 3$ & $13.85 \pm 0.26$ \\
\hline \multirow{2}{*}{\multicolumn{2}{|c|}{$\begin{array}{l}\text { Protein digestibility (\%) } \\
\text { Total dietary fiber ( } \mathrm{g} / \text { serving } \\
\text { portion of } 30 \mathrm{~g})^{\star}\end{array}$}} & $71.61 \pm 1.11$ \\
\hline & & \\
\hline
\end{tabular}

*theoretical value calculated through the chemical composition of the raw materials.

\section{Conclusions}

The breakfast cereal produced presented a healthy choice, giving benefits, such as source of dietary fiber, moderate glycemic index, low glycemic load, good protein digestibility and with considerable levels of essential fatty acids.

\section{Acknowledgement}

To CNPq and FAPESP for granting the scholarships and for R\&S Blumos for the donation of defatted chia flour.

\footnotetext{
${ }^{1}$ WIESIR, H. Chemistry of gluten proteins. Food Microbiology. 2007, 24, 115 119.

${ }^{2} \operatorname{COSTA}$, M. G.; SOUZA, E. L.; STAMFORD, T. L. M.; ANDRADE, S. A. C. Qualidade tecnológica de grãos e farinhas de trigo nacionais e importados. Revista de Ciência e Tecnologia de Alimentos. 2008, 28, 220-225.

3 ROSEll, M. C.; BARRO, F.; SOUSA, C.; MENA, M. C. Cereals for developing gluten-free products and analytical tools for gluten detection. Journal of Cereal Science. 2014, 59, 354-364.
} 